\title{
Tapauksena tapaustutkimus
}

Markus Laine, Jarkko Bamberg \& Pekka Jokinen (toim.) (2007). Tapaustutkimuksen taito. Gaudeamus.

$\prod$ apaustutkimus käsitteenä on hyvin ambivalentti sateenvarjokäsite, joka voidaan ymmärtää laajassa mielessä kokoavaksi tutkimusotteeksi jollain tavalla erityisen, merkittävän, kriittisen tai kiinnostavan tapauksen tarkemmaksi selvittämiseksi. Jotkut katsovat, että laadullisessa tutkimuksessa on aina tavallaan kyse tapauksesta. Lisäksi voidaan todeta, että määrällisestä tutkimuksestakin on mahdollista löytää tapaustutkimuksen tunnusmerkit täyttäviä tutkimuksia, vaikka tyypillisesti tapaustutkimus luetaan laadullisen tutkimuksen piiriin tietynlaisen tapauksen määrittelyongelman takia. Tapaustutkimukset saattavat usein olla myös eri tutkimustapoja ja -aineistoja yhdistäviä.

Kasvatustieteiden piirissä samoin kuin tapaustutkimusta soveltavilla lähitieteenaloillakin - tutkitaan tapaustutkimuksena jotakin ilmiötä kokonaisvaltaisesti ja koetetaan paljastaa tapausesimerkin avulla ilmiön luonnetta, muutoksen logiikkaa, toimijoiden roolia, osallisten kokemuksia ja niin edelleen. Tutkimukseen valitulla tapauksella sinänsä voi olla yleisempääkin merkittävyyttä, mutta tärkeältä näyttävät pyrkimykset tuottaa intensiivistä ja yksityiskohtaista tietoa tutkittavasta tapauksesta (Gomm, Hammersley \& Foster 2000).

Tapaustutkimuksen taito -kirja on tekijöidensä mukaan ensimmäinen suomenkielinen kirja, jonka tavoitteena on syvällisesti paneutua tapaustutkimuksen saloihin. Kansainvälisestä kirjallisuudesta löytyy useampia tapaustutkimuksesta kirjoitettuja teoksia, joista ehkä Robert K. Yinin (2003) kolmanteen painokseen ehtinyt teos on yksi käytetyimmistä lähteistä. Aika näyttää tuleeko Tapaustutkimuksen taito -kirjalle vastaavanlaista menestystä. Ainekset siihen ovat kohtuullisen hyvät, sillä jo ensilukemasta lähtien kirjasta paistaa läpi tekijöiden perusteellinen paneutuminen tapaustutkimuksen maailmaan niin omakohtaisen tutkimustyön kuin lähtökohtien tarkemman analysoimisen kautta.

Kirjoittajia on yhteensä kaksitoista, jotka neljäntoista artikkelin kautta pohtivat tapauksen löytämistä ja rajaamista, teoriaa tapaustutkimuksessa, tapaustutkimuksen kertomaa sekä tutkijan roolia. Hyvin olennaisia asioita siis. Pääosa heistä on yhdyskuntatieteiden ja yhteiskuntapolitiikan aloilta, mutta mukana on myös muita yhteiskuntatieteilijöitä.

Artikkeleita on siis runsaasti, joten otan tässä tarkasteluun vain näytteeksi muutamia. Eräänlaiselta kynnyskysymykseltä kirjan perusteella näyttää itse tapauksen määrittely: sen valinta, rajaaminen ja kehkeytyminen tutkimuskohteena. Miten kirjoittajat käsittelevät tätä problematiikkaa? Mikä tekee juuri tietystä tapauksesta tapaustutkimukseen arvokkaan tai erityisen kohteen? Sitähän jokaisen tapaustutkimuksen tekijän olisi syytä pohtia.
Kirjan toimittajakolmikko, Markus Laine, Jarkko Bamberg \& Pekka Jokinen, on avausartikkelissaan ottanut muista kirjan teksteistä poiketen selkeän määrittelylinjan. Heidän ratkaisunsa on siten hyvin yksinkertainen: kaikissa empiirisissä tutkimuksissa käsitellään tapauksia. He myös määrittelevät tapaustutkimuksen kohteen sellaiseksi tapahtumakuluksi tai ilmiöksi, jossa tarkastellaan vain pientä joukkoa tapauksia, usein vain yhtä tiettyä tapausta. Perusteellinen ja tarkkapiirteinen kuvaus - ja monipuolinen aineisto - ovat heidän mielestään onnistumiseen vaadittavia asioita.

Ongelmallinen on kuitenkin tapaustutkimusotteen vertailu tilastolliseen tutkimukseen. Tässä yhteydessä kirjoittajat toteavat määrällisen tutkimuksen tapauksena olevan vain tilastollisen yksikön eli yhden vastaajan. Tietyssä mielessä esimerkiksi laajassa survey-tutkimuksessa näin onkin, mutta entäpä jos kokoamme tilastollisen aineiston joukolta vapaan sivistystyön aikuisopiskelijoita ja katsomme tuloksia kokonaisuutena tapauksena (tietyn ikäiset toimijat tietyssä kontekstissa) kuin yleistäen tuloksia kaikkiin suomalaisiin aikuisopiskelijoihin (joista tutkittavat ovat otokseen poimittuja tilastoyksiköitä)? Tämänkaltaiset vastakkainasettelun vaikeudet näissä yksinkertaistuksissa helposti piilevät. Toki kirjoittajat myöntävät sosiaalisten ilmiöiden olevan aina kompleksisia ja usein tarvitaankin triangulaatiota - montaa menetelmää, aineistoa tai näkökulmaa yhdessä.

Liisa Häikiö ja Vivi Niemenmaa pitävät omassa aineistos- 
saan ja esimerkissään ohjenuorana käytäntö- ja aineistolähtöisyyttä. Tapauksen määrittely ei ala teoreettisista huomioista, vaan he tarjoavat ratkaisuna vasta tutkimuksen kuluessa tapausten rajojen ja kontekstien määrittämistä. Yksityiskohtainen tietämys erilaisista toimijoista, tapahtumista ja prosesseista on tavoitteena. He muistuttavat, että myös lukija osallistuu tapauksen muotoiluun tulkitessaan tutkimusraportissa esitettyä tapausta.

Annukka Malmstenin artikkelissa ratkaisuna on ollut tarkastella omaa tutkimusesimerkkiä-ympäristökonfliktia-monia ulottuvuuksia ja maantieteellisiä mittasuhteita sisältävänä ilmiönä. Tutkijan kannattaa hänen mielestään tehdä ero pontentiaalisten tutkimuskohteiden (ja näkökulmien) välillä ja pohtia sitä, mitä lähestymistapaa on mielekästä käyttää ja mitä haluaa tutkia tapauksena.

Kimmo Kurunmäen ratkaisuna on puolestaan vertailu. Sen sijaan, että tehtäisiin syväluotaus yhteen yksittäiseen tapaukseen, otetaankin tarkastelunkohteeksi rinnakkain useampia. Luonnollisia vertailuasetelmia löytyy esimerkiksi vertailtaessa jotakin tutkittavaksi valittua ilmiöitä eri maissa. Kurunmäen artikkelissa se on yksityisen ja julkisen sektorin suhteet kaupunkisuunnittelussa Suomessa, Saksassa ja Britanniassa. Tapausta voidaan sitten vertailussa koettaa ymmärtää hyvin monitasoisena paikallisena, kansallisena ja käsitteellisenä ilmiönä.

Tapaustutkimusta voidaan käyttää myös historiallisen prosessin kuvaamiseen, kuten Markus Laine ja Lasse Peltonen artikkelissaan pohtivat. Tapaustutkimuksessa päästään tutkimaan esimerkiksi sosiaalista tai kult- tuurista muutosta tarkastelemalla sellaisia olosuhteita, jännitteitä ja tapahtumakulkuja, jotka ilmenevät muutoksen käynnistäjinä ja mekanismeina. Ongelmana muutoksen tarkastelussa on luonnollisesti kontekstin ja tapauksen kietoutuminen toisiinsa hyvin monimutkaisella tavalla. Todellisia kontekstissa vaikuttavia asiayhteyksiä ei pystytä tutkimusta varten määrittelemään tai rajaamaan kovin tyhjentävästi.

Tapauksen problematiikka tulee kirjassa siis käsiteltyä varsin monipuolisesti ja laaja-alaisesti. Toisaalta artikkeleiden perusteella on varmasti viisasta olla tekemättä liian tarkkoja yrityksiä määritellä, mitä esimerkiksi tapaus on tapaustutkimuksen kohteena tai miten tapaustutkimus pitäisi toteuttaa. Jokainen kirjoittaja on sen tehnyt hyvin omalla tavallaan perustellen ja tutkimuskohdespesifisti. Ehkä se on juuri sitä tapaustutkimuksen taitoa - eräänlaista tasapainoilun taitoa tapauksen valinnan, rajauksen ja kontekstualisoinnin kanssa (s. 107). Kirjan antia ja pohdintoja yhteen vetävää artikkelia lukijana jääkin jollain tavalla kaipaamaan moninaisuuden herättämien kysymysten kokoamiseksi.

Kirjan kansikuvaksi valitut sahat, hohtimet ja viilat pyrkivät luomaan mielikuvia rakentami- sesta tai remontoinnista tietynlaisena tapauksena. Lukijan mielikuvat saattavat tosin karata muuallekin, sillä kansikuva toi mieleeni lähinnä Leevi and the Leavings yhtyeen kappaleen "Vasara ja nauloja”, jossa eräässä kohdin lauletaan: ”...hommat on hanskassa ja hanskat hukassa...”. Tässä tapauksessa - kun tapauksena on tapaustutkimus hanskat tuntuvat olevan kirjoittajilla kuitenkin hyvin tallessa. Joten oletettavasti kirja auttaa myös muita tapaustutkimuksen parissa kamppailevia löytämään omat "hanskansa" eli hahmottamaan paremmin tutkimuksensa tekemisen perusteita. Tutkimushan on aina paitsi tutkimuksen tekemisen käsityötaitoa niin myös tutkimuksen tekemisen lähtökohtien parempaa ymmärtämistä. Siksi toivon lämpimästi, että Tapaustutkimuksen taito kirja löytää lukijakuntansa myös kasvatus- ja aikuiskasvatustieteiden piiristä.

\section{Viitteet}

Gomm, R., Hammersley, M. \&

Foster, P. (Eds.) (2000). Case study method. Key issues, key texts. London: Sage.

Yin, R.K. (2003). Case study research. Design and methods. $3^{\text {rd }}$ edition. London: Sage.

\section{VESA KORHONEN}

